\title{
IMPLEMENTASI ALGORITMA A-STAR DALAM MENENTUKAN RUTE PENGEJARAN OPTIMAL PADA PERMAINAN MEMBASMI NARKOBA
}

\section{THE IMPLEMENTATION OF A-STAR ALGORITHM TO DETERMINE OPTIMAL PURSUE ROUTES IN DRUG ERADICATION GAME}

\author{
Lukas Tommy $1^{1}$, Yohanes Setiawan Japriadi $2^{2}$, Syachriza Hilmaida Habibur $3^{3}$ \\ ${ }^{1,2,3}$ Program Studi Teknik Informatika, Fakultas Teknologi Informasi, ISB Atma Luhur \\ ${ }^{1}$ lukastommy@ atmaluhur.ac.id, ${ }^{2}$ ysetiawanj@ atmaluhur.ac.id, \\ 31611500099@mahasiswa.atmaluhur.ac.id
}

\begin{abstract}
Abstrak
Narkoba memiliki beberapa dampak negatif seperti ketergantungan, kerusakan otak dan saraf, hingga kematian jika disalahgunakan. Sosialisasi mengenai bahaya penyalahgunaan narkoba di masyarakat oleh pihak kepolisian masih dilaksanakan secara konvensional sehingga kurang efektif terlebih di masa pandemi Covid-19 seperti saat ini. Pada penelitian ini akan diusulkan sebuah permainan Android yang dapat menyampaikan materi bahaya narkoba dengan menarik, interaktif, dan efektif. Pada permainan yang diusulkan, kecerdasan buatan akan diterapkan pada musuh agar dapat mengejar pemain dengan melalui rute yang optimal. Salah satu algoritma penentuan rute terdekat dari lokasi awal menuju tujuan adalah A-Star. Algoritma A-Star memanfaatkan heuristik dalam mengevaluasi simpul yang ada pada peta berbentuk grid sehingga waktu komputasinya lebih singkat dibandingkan Dijkstra. Berdasarkan analisis yang sudah dilaksanakan diketahui bahwa secara keseluruhan kinerja dari algoritma A-Star sudah baik dimana tujuh musuh di permainan dapat mengejar pemain secara real-time melalui rute yang optimal. Musuh namun tidak mampu untuk bekerja sama dalam mengepung pemain dan cenderung untuk berkumpul di satu titik dengan melalui rute yang sama sehingga efektivitas pengejaran tidak maksimal. Permainan yang diusulkan juga dapat menyampaikan materi mengenai jenis-jenis narkoba dan dampak negatifnya dengan menarik, interaktif, sekaligus efektif melalui menu gamepedia sekaligus karakter musuh yang ditampilkan di sepanjang permainan.
\end{abstract}

Kata kunci: algoritma, A-Star, narkoba, pathfinding, permainan

\begin{abstract}
Drugs have several negative effects such as dependence, brain and nerve damage, to death if abused. Socialization about the dangers of drug abuse in society by police is still carried out conventionally so that it is less effective especially during the Covid-19 pandemic like today. In this research, an Android game that can convey material on the dangers of drugs in an interesting, interactive, and effective way will be proposed. In the proposed game, an artificial intelligence will be applied to the enemies in order to pursue player through optimal route. One of the algorithms for determining the closest route from the initial location to the destination is A-Star. A-Star algorithm utilize heuristics in evaluating nodes on a grid-shaped map so that its computation time is shorter than Dijkstra's. Based on the analysis that has been carried out, it is known that the overall performance of A-Star algorithm is good where the seven enemies in game can pursue player in real-time through optimal route. The enemies, however, are unable to cooperate in surround player and tend to gather at one point through the same route so that the effectiveness of the pursuit is not maximized. The proposed game can also convey material about the types of drugs and their negative impacts in an interesting, interactive, and effective manner through with gamepedia menu as well as the enemy characters displayed throughout the game.
\end{abstract} Keywords: algorithm, A-Star, game, drugs, pathfinding

\section{PENDAHULUAN}

Awalnya narkoba atau napza (singkatan dari narkotika, psikotropika, dan obat terlarang) diperuntukkan sebagai obat bius atau obat bagi penyakit tertentu. Persepsi tersebut kemudian berubah 
dikarenakan narkoba sering disalahgunakan untuk rekreasional dan doping [1]. Beberapa komplikasi yang akan timbul dari penyalahgunaan narkoba antara lain ketergantungan, penurunan kesadaran, gangguan psikis, kerusakan otak dan saraf, hingga kematian.

Strategi yang diterapkan oleh pihak kepolisian untuk mencegah terjadinya penyalahgunaan narkoba di masyarakat masih berupa sosialisasi langsung. Strategi ini dirasakan kurang efektif [2] jika dilihat dari masih cukup tingginya jumlah kasus penyalahgunaan narkoba di Indonesia, yaitu menurut data dari BNN (Badan Narkotika Nasional) di sepanjang tahun 2019 terungkap 33.371 kasus dimana sebagian besar adalah generasi milenial (usia remaja hingga dewasa muda) [3]. Hal ini diduga disebabkan oleh peserta dari generasi milenial kurang tertarik untuk membaca brosur dan mendengarkan sosialisasi bahaya narkoba dimana disampaikan secara monoton [2]. Selain itu, di masa pandemi Covid-19 ini, sosialisasi langsung dikhawatirkan dapat membentuk klaster penularan Covid-19 baru dan pembatasan jumlah peserta membuat strategi ini semakin tidak efektif [4].

Untuk mengatasi permasalahan tersebut, diperlukan strategi penyampaian bahaya narkoba yang menarik, efisien, sekaligus interaktif agar partisipasi masyarakat menjadi meningkat. Strategi berupa aplikasi pengenalan jenis narkoba berbasis Android [2] masih kurang menarik karena aplikasi yang dihasilkan tidak jauh berbeda dengan brosur elektronik. Berdasarkan hal tersebut, akan diusulkan game / permainan berbasis Android yang memiliki pesan mendidik terkait bahaya narkoba.

Game dapat disisipkan suatu materi pelajaran, sehingga tingkat pemahaman pengguna terhadap materi tersebut menjadi meningkat hanya dengan memainkannya. Selain itu, dengan konsep penyampaian materi dalam bentuk permainan yang interaktif membuat pengguna tidak mudah bosan, sehingga penyampaian materi menjadi lebih efektif [5].

Genre dari permainan yang diusulkan adalah Third-Person Shooter (TPS) dengan mempertimbangkan kepopuleran permainan ber-genre tersebut (misalkan Free Fire dan Player Unknown Battle Ground (PUBG)) dibandingkan genre lainnya [6]. TPS merupakan jenis permainan tembak-menembak dimana karakter yang dimainkan oleh pemain terlihat di layar selama permainan. Adapun Android dipilih sebagai platform sasaran dikarena jumlah pengguna perangkatnya jauh lebih banyak jika dibandingkan platform lain [7].

Permainan yang diusulkan bersifat single player sehingga kecerdasan buatan perlu untuk diterapkan pada karakter musuh agar permainan menjadi menarik dan lebih menantang [8]. Dengan kecerdasan buatan ini, karakter musuh pada permainan dapat mengejar karakter yang digerakkan oleh pemain dengan melalui rute yang optimal (terdekat).

Terdapat beberapa algoritma yang dapat digunakan dalam penentuan rute terdekat dari lokasi awal menuju tujuan, diantaranya Dijkstra, A-star, Bellman-Ford, Floyd-Warshall, dan Dynamic PathFinding Algorithm [8-9] dimana yang paling populer adalah Dijkstra dan A-Star.

Algoritma Dijkstra umumnya diterapkan dalam menentukan rute terpendek antar dua titik pada peta sesungguhnya dimana peta ini diwakili dalam bentuk graf. Contoh penerapannya antara lain untuk penentuan rute terpendek lokasi tempat wisata [9-10], SPBU (Stasiun Pengisian Bahan Bakar Umum) [11], dan halte TransJakarta [12]. Algoritma Dijkstra juga dapat diterapkan topologi jaringan dan protokol routing seperti Open Shortest Path First (OSPF) [13]. Algoritma Dijkstra adalah jenis dari algoritma greedy dan node yang sudah ditelusuri tidak dapat ditelusuri kembali, sehingga terkadang rute yang dihasilkan bukan optimum secara global [14]. Selain itu, meskipun algoritma Dijkstra selalu dapat menemukan rute, namun proses komputasinya kompleks karena membandingkan biaya jalur satu dengan lainnya [15] sehingga membutuhkan waktu yang lebih lama jika dibandingkan dengan A-star [16].

Berbeda halnya dengan Dijkstra, algoritma A-Star biasanya diimplementasikan dalam mencari jalur terdekat dari titik awal ke titik tujuan pada peta permainan yang direpresentasikan dalam bentuk grid [8]. Contoh penerapan A-Star adalah seperti untuk NPC (Non-Playable Character) dalam 
mencari rute terpendek pada lintasan di permainan balap mobil [8] dan menuju sebuah titik dalam permainan Snake 3D [17] dengan menghindari hambatan yang ada. Algoritma A-Star juga dapat digunakan sebagai bantuan dalam mencari rute tependek ke titik finish di permainan labirin [18] sekaligus sebagai input dalam penyebaran titik-titik penempatan objek di peta permainan secara acak [19]. A-Star menggunakan heuristik dalam proses penentuan rute terpendeknya sehingga waktu komputasinya lebih singkat dibandingkan Dijkstra [14-15].

Dalam perkembangannya, beberapa modifikasi telah dilakukan terhadap algoritma A-Star seperti memadukannya dengan DPA [8]. Kombinasi ini memungkinkan mobil yang dikendalikan oleh komputer menjadi lebih baik dalam menghindari hambatan dinamis (bergerak) yang muncul di sepanjang permainan. Kombinasi ini namun lebih kompleks dibandingkan A-Star biasa sehingga waktu komputasinya sedikit lebih lama [8]. Selain itu, pada permainan yang diusulkan tidak terdapat hambatan dinamis sehingga $A$-Star standar akan lebih cocok untuk diterapkan pada musuh agar dapat mengejar pemain secara real-time.

Berdasarkan latar belakang yang telah diuraikan, terdapat beberapa hal penting yang perlu diperhatikan dalam mengenalkan bahaya narkoba melalui permainan yang diusulkan. Pertama, musuh-musuh di permainan berwujud narkoba yang jenisnya bervariasi dan dapat mengejar pemain dengan menggunakan algoritma A-Star. Kedua, pemain dapat menggerakkan karakter untuk membasmi musuh-musuh yang ada dengan kontrol layaknya game ber-genre TPS populer. Terakhir, permainan dapat menampilkan informasi detail mengenai jenis-jenis dan karakteristik narkoba, serta bahaya yang dikandungnya.

Permainan yang diusulkan diharapkan dapat menjadi media yang menarik, interaktif, serta efektif dalam menyampaikan bahaya penyalahgunaan narkoba kepada masyarakat Indonesia, khususnya generasi milenial. Selain itu juga diharapkan kinerja dari algoritma A-Star dalam menentukan rute optimal antara musuh-musuh yang ada menuju karakter pemain dapat dianalisa secara rinci dan dapat berjalan secara real-time.

\section{METODOLOGI}

\subsection{Metode Pengumpulan Data}

Metode pengumpulan data yang digunakan dalam penelitian ini adalah studi pustaka dimana buku-buku dan penelitian terkait jenis-jenis, karakteristik, dan bahaya dari narkoba dipelajari. Hingga saat ini, terdapat 73 jenis narkoba yang beredar di Indonesia dan 803 jenis narkoba beredar di dunia [3]. Pada penelitian ini hanya 7 diantaranya saja yang paling populer yang akan dibahas, seperti yang dapat dilihat di Tabel 1.

\subsection{Algoritma $A$-Star}

Algoritma A-Star adalah algoritma BFS (Best First Search) yang mengkombinasikan greedy BFS dengan uniform cost search. Fungsi heuristik digunakan greedy BFS untuk mengestimasi biaya dari titik awal menuju titik tujuan, sedangkan jarak terpendek dari titik awal menuju titik selanjutnya hingga titik tujuan dipilih oleh uniform cost search [20]. Algoritma A-Star akan mendapatkan jalur yang lengkap, yaitu solusi selalu didapatkan apabila memang ada, sekaligus optimal dengan heuristik. Selain itu, waktu komputasi A-Star cenderung cepat karena titik dengan nilai heuristik kecil (diperkirakan lebih dekat dengan tujuan) akan dievaluasi lebih dulu [16].

Adapun fungsi evaluasi dari algoritma A-Star dapat dihitung dengan Persamaan (1) dimana $f(n)$ adalah perkiraan total biaya rute melalui $n$ ke tujuan. Sementara itu $g(n)$ merupakan biaya sejauh ini untuk mencapai $\mathrm{n}$ dan $h(n)$ adalah perkiraan biaya dari $\mathrm{n}$ ke tujuan [15].

$$
f(n)=g(n)+h(n)
$$


Jurnal Elektro Telekomunikasi Terapan Juli 2021

Tabel 1 Jenis Narkoba dan Dampak Negatifnya[1]

\begin{tabular}{|l|l|l|}
\hline No & \multicolumn{1}{|c|}{ Jenis } & \multicolumn{1}{c|}{ Dampak Negatif } \\
\hline 1 & Opium & $\begin{array}{l}\text { Penurunan kesadaran, mengantuk, lesu, penglihatan kabur, dan } \\
\text { sembelit }\end{array}$ \\
\hline 2 & Morfin & $\begin{array}{l}\text { Diabetes, gangguan hormon, tulang rapuh dan mudah patah, } \\
\text { resiko infeksi lebih tinggi, dan disfungsi seksual }\end{array}$ \\
\hline 3 & Sabu Sabu & $\begin{array}{l}\text { Serangan jantung, tekanan darah tinggi, masalah mulut dan gigi, } \\
\text { kerusakan otak, halusinasi, gangguan kecemasan, dan depresi }\end{array}$ \\
\hline 4 & Kokain & $\begin{array}{l}\text { Stroke, kejang-kejang, tremor, koma, ketergantungan, depresi, } \\
\text { insomnia, gangguan seksual, serangan jantung, gangguan } \\
\text { pencernaan dan pernapasan, dan gagal ginjal }\end{array}$ \\
\hline 5 & Ganja & $\begin{array}{l}\text { Mengganggu kemampuan berpikir, iritasi paru-paru, serta } \\
\text { masalah konsentrasi dan daya ingat }\end{array}$ \\
\hline 7 & Ekstasi & $\begin{array}{l}\text { Depresi, konsentrasi menurun, depresi, mudah tersinggung, } \\
\text { sulit tidur, penyakit jantung, sakau, dan overdosis }\end{array}$ \\
\hline Heroin & $\begin{array}{l}\text { Mulut kering, badan terasa berat, mual, kulit gatal, sembelit, } \\
\text { gangguan pernapasan, kekebalan tubuh menurun, gangguan } \\
\text { hati, mandul, gangguan seksual, gangguan saraf }\end{array}$ \\
\hline
\end{tabular}

Musuh pada permainan yang diusulkan dapat bergerak ke arah mana saja sehingga digunakan euclidean distance untuk menghitung nilai heuristik. Euclidean distance adalah jarak di antara dua titik pada ruang euclidean [9]. Persamaan (2) digunakan untuk menghitung nilai heuristik dengan euclidean distance dimana $h(n)$ adalah jarak antara 2 titik, $n . x$ dan goal. $x$ adalah koordinat sumbu $\mathrm{x}$ (horizontal) dari titik saat ini dan tujuan. Sementara itu, n.y dan goal.y adalah koordinat sumbu y (vertikal) dari titik saat ini dan tujuan $[17,20]$.

$$
h(n)=\sqrt{(n \cdot x-\text { goal. } x)^{2}+(n \cdot y-\text { goal.y })^{2}}
$$

Dalam perhitungan A-Star terdapat istilah open list dan closed list. Open list berisikan data titik yang mungkin dilalui dari titik awal maupun titik saat ini. Sementara itu, closed list berisikan data titik sebelum titik saat ini yang juga merupakan bagian dari rute terpendek yang telah berhasil diperoleh [21]. Adapun alur proses dari algoritma A-Star dalam menentukan rute terpendek menuju titik tujuan adalah sebagai berikut [22]:

a. Inisialisasi open list dan masukkan titik awal

b. Inisialisasi closed list

c. Selama open list tidak kosong:

1) Temukan titik dengan $f$ terkecil di open list, namakan $q$

2) Keluarkan $q$ dari open list

3) Hasilkan 8 suksesor $q$ dan atur parent menjadi $q$

4) Untuk setiap suksesor:

a) Hentikan pencarian jika suksesor adalah tujuan

b) Jika titik dengan posisi sama dengan suksesor ada di open list dan $f$-nya lebih rendah dari suksesor, lewati suksesor ini

c) Jika titik dengan posisi sama dengan suksesor ada di closed list dan $f$-nya lebih rendah dari suksesor, lewati suksesor ini, jika tidak, tambahkan titik ke open list

5) Tambahkan $q$ ke closed list 


\subsection{Representasi Peta}

Setiap permainan mempunyai peta yang dimanfaatkan sebagai daerah permainan itu berlangsung. Peta ini perlu direpresentasikan agar dapat digunakan oleh algoritma pencarian rute seperti A-Star dalam permainan [8]. Representasi peta yang digunakan dalam penelitian ini adalah representasi grid. Grid dimanfaatkan untuk membagi peta menjadi cell teratur yang umumnya berbentuk kotak. Dalam pemrograman, grid biasanya diwakili dengan array 2 dimensi dimana setiap cell ini memiliki nilai 1 atau 0 yang menandakan dapat dilalui atau tidaknya cell tersebut.

Adapun grid yang digunakan dalam permainan yang diusulkan berbentuk kotak dengan ukuran 25 baris dan 44 kolom dengan beberapa cell yang tidak dapat dilalui seperti yang ditunjukkan Gambar 1. Ukuran grid tidak terlalu besar dan juga tidak terlalu kecil dikarenakan terdapat 7 musuh komputer yang harus dapat mengejar pemain secara real-time. Grid yang berukuran terlalu besar akan meningkatkan waktu komputasi dan penggunaan resource perangkat secara signifikan [8] sehingga dikhawatirkan kinerja algoritma $A$-Star menjadi kurang baik.

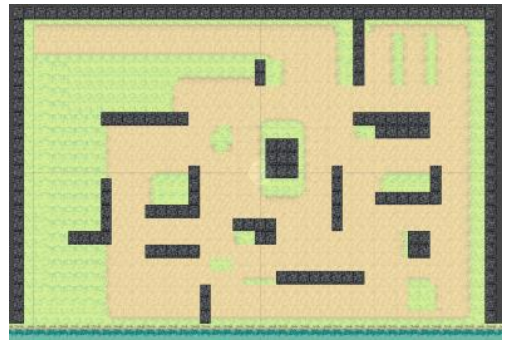

(a)

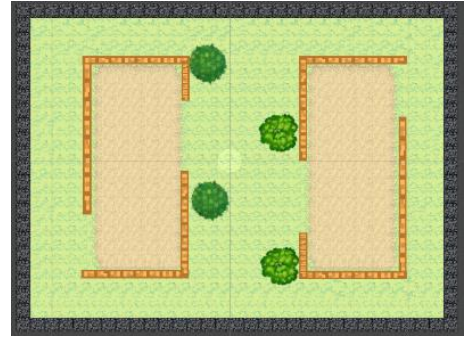

(b)

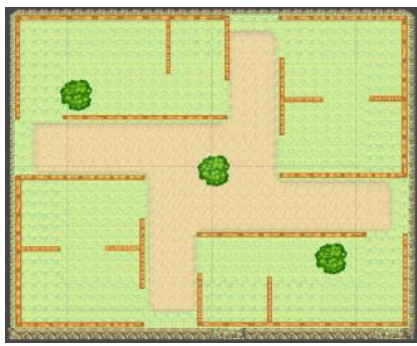

(c)

Gambar 1. Peta Permainan yang Diusulkan (a) Level 1 (b) Level 2 (c) Level 3

\section{PEMBAHASAN}

\subsection{Analisis Kebutuhan Pengguna}

Analisis kebutuhan pengguna dari permainan usulan direpresentasikan dengan use case diagram yang ditunjukkan Gambar 2. Pengguna pada menu utama dapat melihat skor tertinggi, melihat informasi terkait jenis-jenis narkoba dan dampak negatifnya, serta keluar dari permainan. Selain itu saat permainan berlangsung, pengguna dapat menggerakkan karakter, merotasi sudut pandang karakter, menembak sekaligus terkena serangan musuh yang ada.

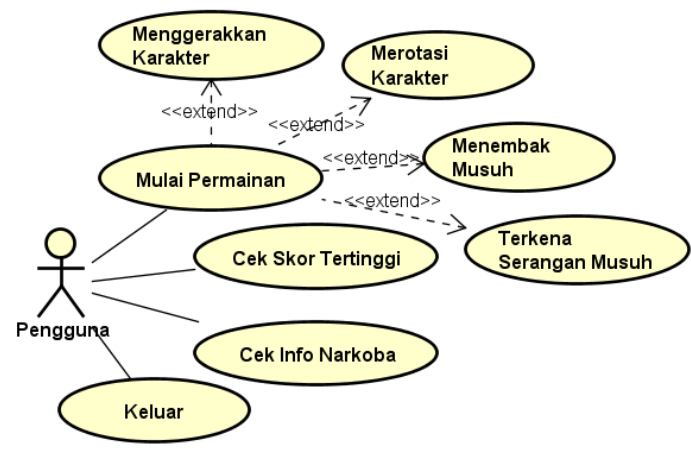

Gambar 2. Use Case Diagram Permainan Usulan

\subsection{Analisis Sistem Usulan}

Analisa gameplay dari permainan usulan direpresentasikan dengan activity diagram yang ditunjukkan Gambar 3 dimana activity diagram ini menunjukkan aliran gameplay dari permainan secara garis besar. 


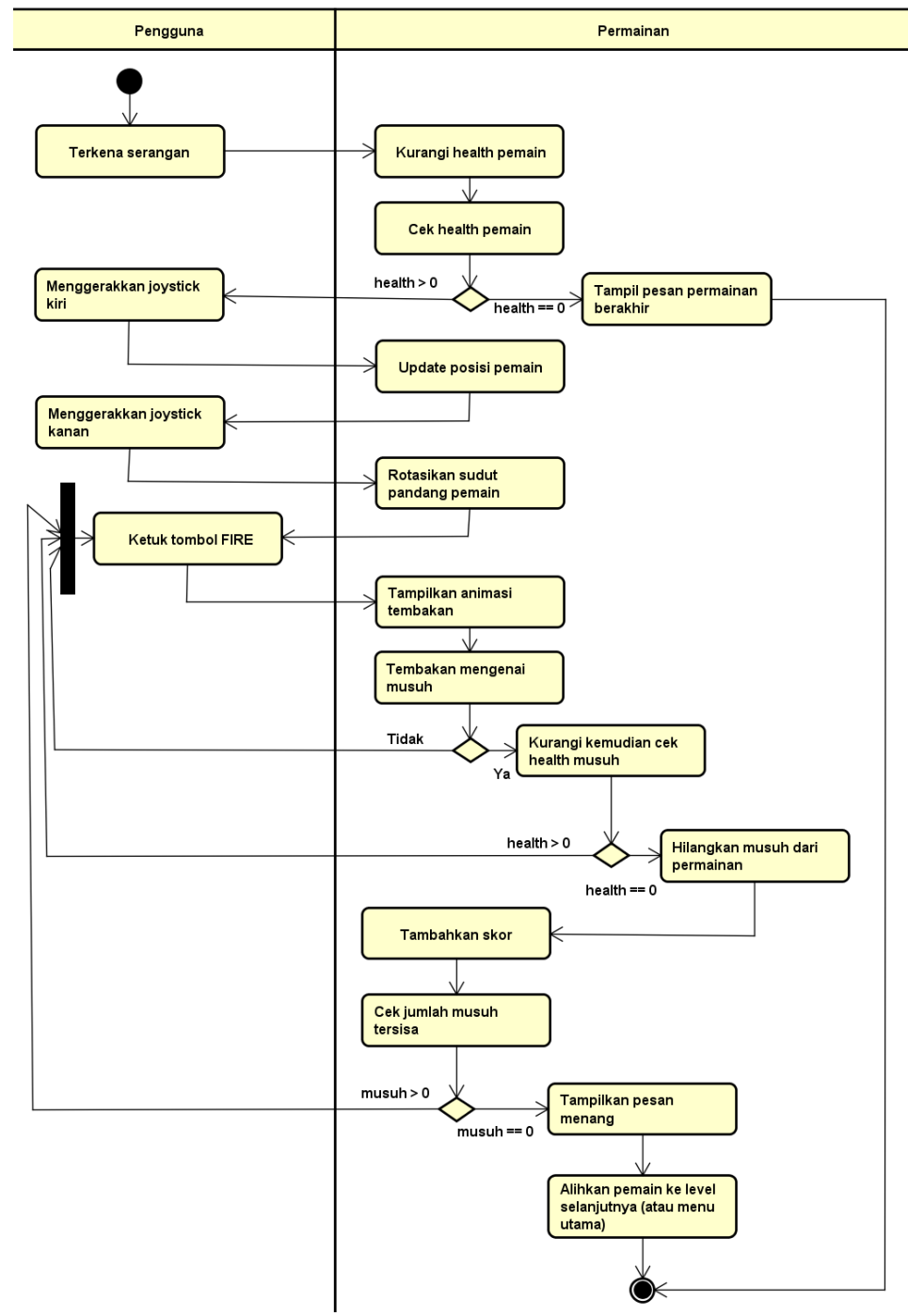

Gambar 3. Activity Diagram Gameplay dari Permainan yang Diusulkan

\subsection{Tampilan Layar}

Gambar 4 merupakan tampilan halaman permainan dari permainan yang diusulkan. Pada halaman ini terdapat beberapa objek seperti karakter pemain, karakter musuh, bar nyawa pemain, skor, jumlah musuh yang tersisa, tombol joystick kiri untuk menggerakkan karakter pemain, tombol joystick kanan untuk mengarahkan pandangan pemain, tombol pause untuk memberikan jeda, dan tombol fire untuk menembak musuh. Pada permainan ini terdapat 3 level dengan peta berbeda dimana semakin tinggi level, kecepatan perpindahan musuh akan semakin bertambah. Karakter musuh yang berjumlah 7 ini akan digerakkan secara otomatis menuju pemain dengan algoritma A-Star.

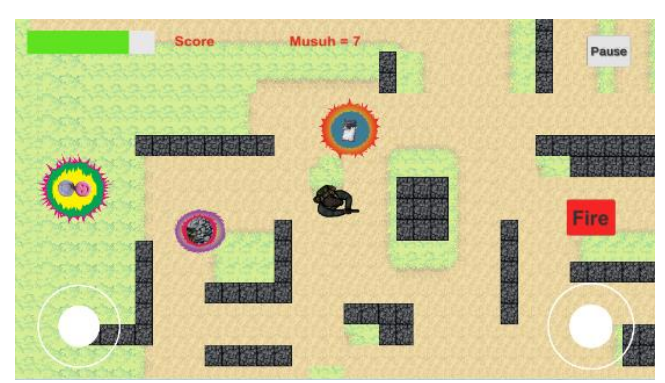

Gambar 4. Tampilan Halaman Permainan 
Gambar 5 merupakan tampilan halaman gamepedia yang berisikan informasi mengenai narkoba. Informasi ini berupa foto, nama, dampak negatif (lihat Tabel 1), serta hukuman penjara bagi pengguna narkoba tersebut.

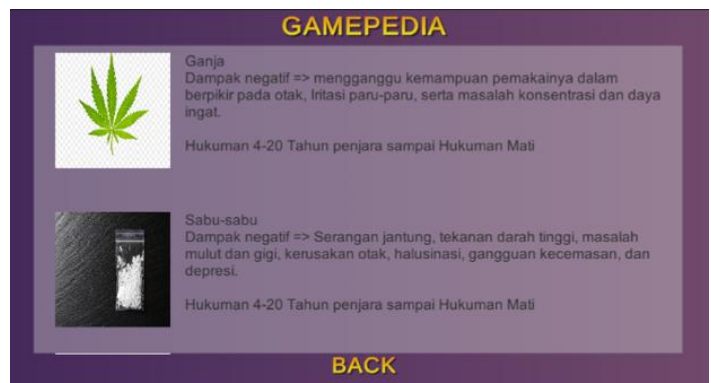

Gambar 5. Tampilan Halaman Gamepedia

\subsection{Analisis Kinerja Algoritma A-Star}

Pada permainan ini algoritma A-Star digunakan oleh setiap musuh untuk menentukan rute pengejaran optimal antara lokasi musuh dengan lokasi pemain saat ini pada grid yang ada. Algoritma A-Star memerlukan grid $\mathrm{x}, \mathrm{y}$ yang meliputi seluruh peta permainan. Setiap cell di grid ini menjadi titik (simpul) dan terbagi menjadi 2, yaitu titik yang bisa dilalui ataupun tidak bisa dilalui. Setelah itu rute pengejaran yang optimal akan ditentukan dengan melalui titik-titik yang dapat dilalui tersebut. Sebagai contoh, salah satu musuh berada di $\operatorname{cell}(3,2)$ dan pemain berada di $\operatorname{cell}(6,3)$ seperti yang ditunjukkan Gambar 6.

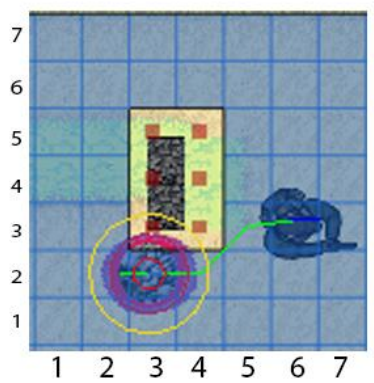

Gambar 6. Langkah ke-1 Pathfinding oleh A-Star

Berdasarkan Gambar 6, algoritma A-Star akan mengevaluasi cell-cell di sekitarnya dengan urutan searah jarum jam. Mula-mula masukkan cell $(4,2)$ ke dalam closed list dikarenakan cell atas $(3,3)$ dan kanan atas $(4,3)$ dari cell saat ini dilewati karena merupakan titik yang tidak dapat dilalui. Perhitungan untuk cell yang titik koordinatnya semakin jauh dari cell pemain seperti $(2,3),(2,2)$, dan $(2,1)$ juga akan dilewati karena pasti memiliki nilai estimasi yang lebih besar dari cell lain. Mula-mula nilai cell $(4,2)$ yang dilalui jika musuh bergerak ke arah kanan sebanyak satu cell akan dihitung seperti yang ditunjukkan Tabel 2.

Cell $(4,2)$ berikut nilai $f$-nya lalu ditambahkan ke open list dan sekarang dilakukan perhitungan terhadap nilai cell $(4,1)$ dan $(3,1)$ dimana kedua cell ini berikut nilai $f$-nya ditambahkan ke open list. Pada cell $(4,1)$ nilai $g$ ditambahkan 1.414 (hasil dari $\sqrt{(1)^{2}+(1)^{2}}$ ) karena musuh bergerak diagonal. Hal ini berarti musuh memprioritaskan untuk bergerak horisontal atau vertikal dibandingkan diagonal jika nilai heuristiknya sama atau sedikit lebih buruk. Sekarang dari ketiga cell yang ada di open list akan dipilih cell dengan $f$ terendah, yaitu cell $(4,2)$. Cell ini kemudian dikeluarkan dari open list agar tidak dihitung kembali. Musuh saat ini berada di cell $(4,2)$ seperti yang ditunjukkan Gambar 7. 
Tabel 2 Langkah ke-1 Perhitungan Nilai Cell dengan A-Star

\begin{tabular}{|c|c|c|c|}
\hline $\begin{array}{c}\text { Cell Saat } \\
\text { Ini }\end{array}$ & $\begin{array}{c}\text { Cell yang } \\
\text { Dievaluasi }\end{array}$ & Nilai & Dipilih \\
\hline \multirow[t]{3}{*}{$(3,2)$} & $(4,2)$ & $\begin{array}{l}g=0+1=1 \\
h=\sqrt{(4-6)^{2}+(2-3)^{2}}=\sqrt{5}=2.236 \\
f=1+2.236=3.236\end{array}$ & $(\checkmark)$ \\
\hline & $(4,1)$ & $\begin{array}{l}g=0+1.414=1.414 \\
h=\sqrt{(4-6)^{2}+(1-3)^{2}}=\sqrt{8}=2.828 \\
f=1.414+2.828=4.242\end{array}$ & \\
\hline & $(3,1)$ & $\begin{array}{l}g(3,1)=0+1=1 \\
h(3,1)=\sqrt{(3-6)^{2}+(1-3)^{2}}=\sqrt{13}=3.606 \\
f(3,1)=1+3.606=4.606\end{array}$ & \\
\hline
\end{tabular}

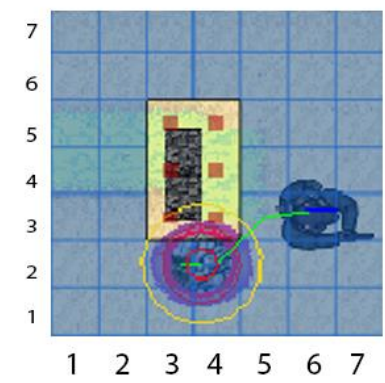

Gambar 7. Langkah ke-2 Pathfinding oleh A-Star

Ulangi langkah-langkah di atas untuk cell(5,3), (5,2), (5,1), dan $(4,1)$ dimana hasil perhitungan keempat cell ini dapat dilihat pada Tabel 3. Cell yang sudah ada di closed list seperti cell $(3,2)$ tidak dievaluasi kembali untuk menghindari perulangan tanpa titik akhir.

Tabel 3 Langkah ke-2 Perhitungan Nilai Cell dengan A-Star

\begin{tabular}{|c|c|c|c|}
\hline $\begin{array}{c}\text { Cell Saat } \\
\text { Ini }\end{array}$ & $\begin{array}{l}\text { Cell yang } \\
\text { Dievaluasi }\end{array}$ & Nilai & Dipilih \\
\hline \multirow[t]{4}{*}{$(4,2)$} & $(5,3)$ & $\begin{array}{l}g=1+1.414=2.414 \\
h=\sqrt{(5-6)^{2}+(3-3)^{2}}=\sqrt{1}=1 \\
f=2.414+1=3.414\end{array}$ & $(\checkmark)$ \\
\hline & $(5,2)$ & $\begin{array}{l}g=1+1=2 \\
h=\sqrt{(5-6)^{2}+(2-3)^{2}}=\sqrt{2}=1.414 \\
f=2+1.414=3.414\end{array}$ & \\
\hline & $(5,1)$ & $\begin{array}{l}g=1+1.414=2.414 \\
h=\sqrt{(5-6)^{2}+(1-3)^{2}}=\sqrt{5}=2.236 \\
f=2.414+2.236=4.65\end{array}$ & \\
\hline & $(4,1)$ & $\begin{array}{l}g=1+1=2 \\
h=\sqrt{(4-6)^{2}+(1-3)^{2}}=\sqrt{8}=2.828 \\
f=2+2.828=4.828\end{array}$ & \\
\hline
\end{tabular}

Berdasarkan Tabel 3, nilai awal dari $g$ bernilai 1 dikarenakan cell saat ini $(4,2)$ berjarak 1 cell dari titik awal $(3,2)$. Cell $(5,3),(5,2)$, dan $(5,1)$ berikut nilai $f$-nya kemudian ditambahkan ke open list sedangkan nilai $f$ dari cell $(4,1)$ lebih buruk daripada $f$ sebelumnya sehingga dilewati. Dari empat titik 
yang ada di open list, dipilih titik dengan $f$ yang terendah dan paling awal dihitung, yaitu cell $(5,3)$. Cell $(4,2)$ sudah ditelusuri sehingga dimasukkan ke closed list. Musuh saat ini berada di cell $(5,3)$ seperti yang ditunjukkan Gambar 8.

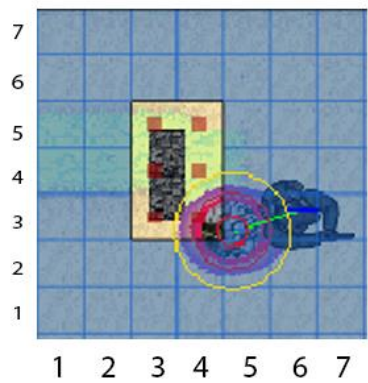

Gambar 8. Langkah ke-3 Pathfinding oleh A-Star

Cell $(5,3)$ kemudian dikeluarkan dari open list dan 8 suksesornya, yaitu cell di sekitarnya dibangkitkan lalu dihitung nilai $f$-nya seperti ditunjukkan Tabel 4 . Saat mengevaluasi nilai cell(6,3), diketahui bahwa nilai heuristiknya adalah 0 atau dengan kata lain cell ini merupakan titik tujuan sehingga pencarian dihentikan karena solusi berupa rute terpendek sudah ditemukan. Cell $(6,3)$ memiliki nilai $f$ sebesar 3.414 yang adalah sama dengan nilai $f$ dari cell parent-nya, yaitu cell $(5,3)$ sehingga A-Star berhasil memprediksi bahwa cell $(5,3)$ mengarah ke solusi yang ada. Nilai $f$ akan berubah apabila terdapat hambatan atau titik yang tidak dapat dilalui. Backtracking kemudian dilakukan agar diperoleh rute pengejaran optimal mulai dari titik tujuan ke titik awal. Parent dari cell $(6,3)$ adalah $(5,3)$, parent dari cell $(5,3)$ adalah $(4,2)$, parent dari cell $(4,2)$ adalah $(3,2)$ dan $\operatorname{cell}(3,2)$ tidak memiliki parent karena adalah titik awal. Rute pengejaran optimal dari cell( $(3,2)$ menuju $(6,3)$ adalah dengan melalui $(4,2)$ dan $(5,3)$ seperti yang ditunjukkan garis hijau pada Gambar 6.

Tabel 4 Langkah ke-3 Perhitungan Nilai Cell dengan A-Star

\begin{tabular}{|c|c|c|c|}
\hline $\begin{array}{c}\text { Cell Saat } \\
\text { Ini }\end{array}$ & $\begin{array}{l}\text { Cell yang } \\
\text { Dievaluasi }\end{array}$ & Nilai & Dipilih \\
\hline \multirow[t]{3}{*}{$(5,3)$} & $(5,4)$ & $\begin{array}{l}g=2.414+1=3.414 \\
h=\sqrt{(5-6)^{2}+(4-3)^{2}}=\sqrt{2}=1.414 \\
f=3.414+1.414=4.828\end{array}$ & \\
\hline & $(6,4)$ & $\begin{array}{l}g=2.414+1.414=3.828 \\
h=\sqrt{(6-6)^{2}+(4-3)^{2}}=\sqrt{1}=1 \\
f=3.828+1=4.828\end{array}$ & \\
\hline & $(6,3)$ & $\begin{array}{l}g=2.414+1=3.414 \\
h=\sqrt{(6-6)^{2}+(3-3)^{2}}=\sqrt{0}=0 \\
f=3.414+0=3.414\end{array}$ & $(\checkmark)$ \\
\hline
\end{tabular}

\subsection{Pengujian Kinerja A-Star}

Agar proses pengujian tidak terlalu kompleks, pengujian kinerja A-Star akan dilakukan pada subgrid berukuran 12 baris dan 12 kolom dari grid permainan level 1 sesungguhnya yang berukuran 25 baris dan 44 kolom. Pada subgrid ini terdapat cell yang tidak dapat dilalui (ditandai dengan warna merah). Selain itu, jumlah musuh yang ada pada subgrid adalah 3 dari 7 musuh dan posisi karakter pemain tidak dipindah selama pengujian berlangsung. Pengujian dilakukan sebanyak 4 kali dengan posisi awal musuh (A, B, C) adalah tetap dan posisi pemain (X) bervariasi. Hasil pengujian kinerja AStar setiap musuh dalam menentukan rute optimal untuk mengejar pemain dapat dilihat pada Tabel 5 . 
Tabel 5 Hasil Pengujian Kinerja A-Star pada Subgrid Level 1

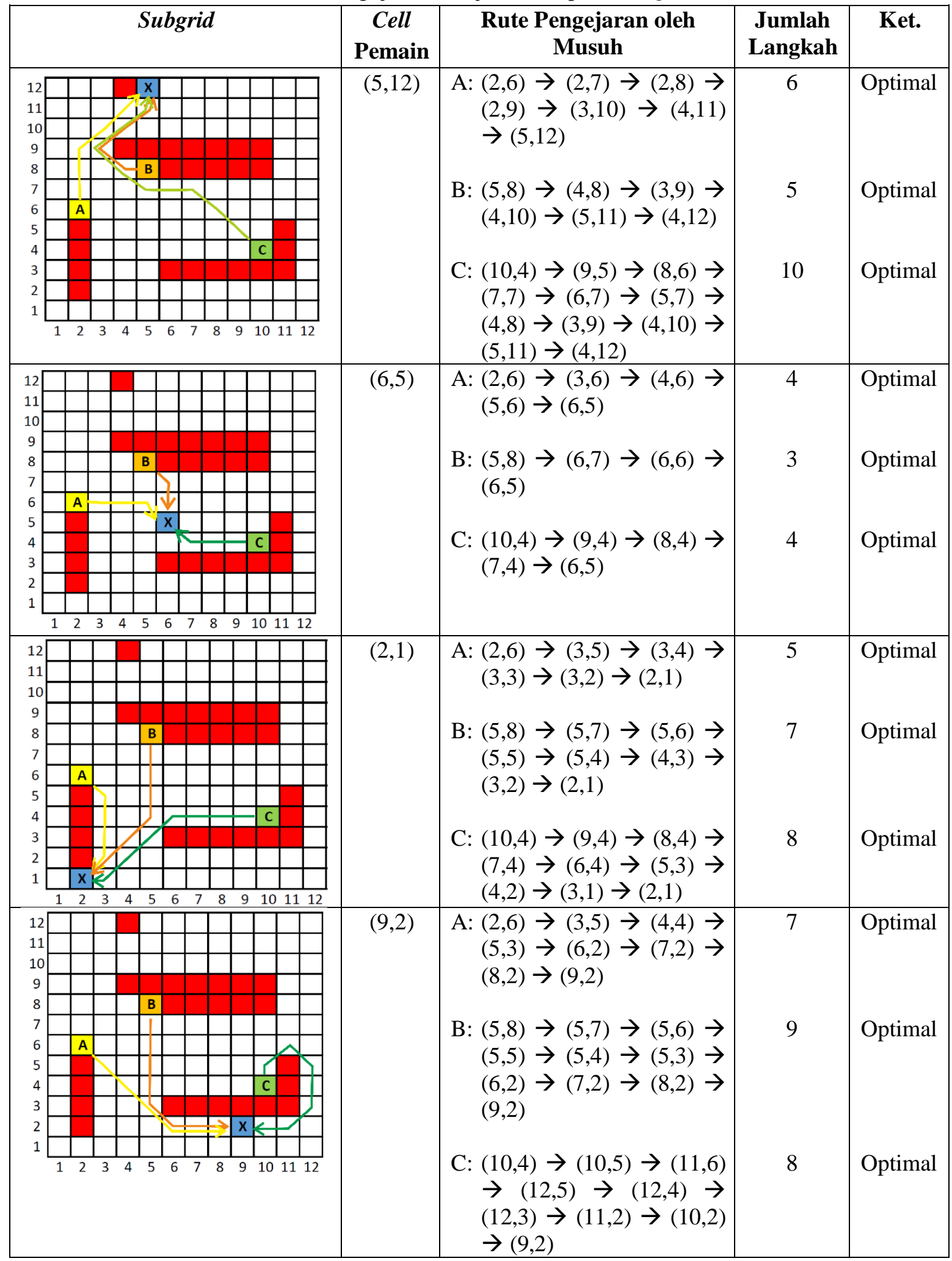

\subsection{Keterbatasan Algoritma Usulan}

Terdapat permasalahan pada algoritma A-Star yang telah diimplementasikan, yaitu tidak terdapat koordinasi antara karakter musuh satu dengan yang lain dalam mengejar dan mengepung pemain. Musuh-musuh yang ada memiliki kecenderungan untuk menuju dan berkumpul di satu titik 
yang sama dengan melalui rute yang sama pula seperti yang ditunjukkan Tabel 5 dan Gambar 9. Hal ini membuat musuh mudah untuk dikalahkan dengan mengumpulkan mereka terlebih dahulu di satu rute sehingga membuat permainan menjadi kurang menantang.

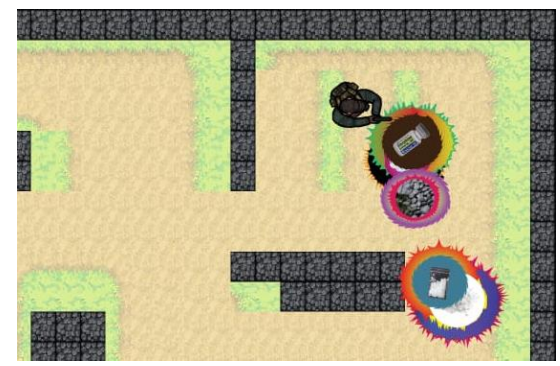

Gambar 9. Musuh-Musuh Berkumpul di Satu Titik

Berdasarkan Gambar 9, musuh yang cerdas seharusnya dapat bekerja sama dan mempertimbangkan kondisi sekitar, misalkan beberapa musuh memilih rute pengejaran di sebelah kiri pemain meskipun lebih jauh. Rute ini namun akan lebih optimal karena dapat menutup rute pelarian karakter pemain dan mengharuskan pemain menembak di dua arah berbeda sehingga membuat permainan menjadi lebih sulit dan menantang.

Eksperimen untuk mengatasi keterbatasan ini sudah dilakukan, salah satunya dengan membuat cell yang ditempati musuh lainnya menjadi tidak dapat dilalui. Hal ini diharapkan dapat membuat musuh yang posisinya lebih jauh untuk memilih jalur alternatif. Strategi ini namun membuat musuh bingung dan melakukan gerakan yang tidak perlu seperti yang ditunjukkan garis kuning di Gambar 10 dengan kondisi karakter pemain tidak digerakkan.

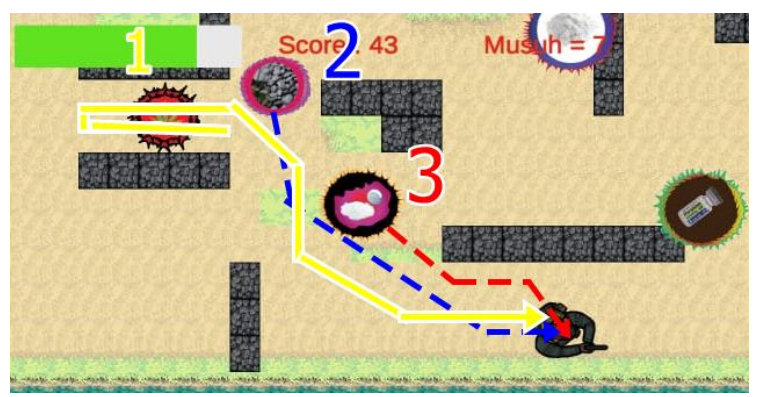

Gambar 10. Rute Pengejaran Berbeda oleh Setiap Musuh

Berdasarkan Gambar 10, mula-mula musuh ke-1 bergerak ke kanan karena diprediksi rute tersebut optimal dan bisa dilalui. Musuh lainnya juga bergerak pada waktu yang sama dan musuh ke2 menempati cell di rute pengejaran musuh ke-1 sehingga membuat cell tersebut tidak dapat dilalui. Hal ini membuat rute pengejaran musuh ke-1 berubah dan dengan mempertimbangkan posisi musuh ke-3 maka dipilihlah rute kiri. Setelah posisi musuh ke-2 cukup jauh dari posisinya semula seperti yang ditunjukkan Gambar 10, musuh ke-1 akan kembali mengambil rute kanan untuk mengejar pemain karena cell yang awalnya tidak dapat dilalui sudah dapat dilalui.

\section{KESIMPULAN}

Penyampaian informasi mengenai dampak negatif penyalahgunaan narkoba kepada pengguna dapat dilakukan secara menarik, interaktif, sekaligus efektif melalui permainan yang diusulkan. Hal ini dikarenakan materi yang tersirat pada media hiburan akan lebih cepat dan mudah untuk dikuasai karena penyampaiannya tidak membosankan. 
Analisis secara mendetail sudah dilaksanakan terhadap kinerja dari algoritma A-Star dalam menentukan rute optimal antara posisi musuh-musuh yang ada menuju posisi karakter pemain. Secara keseluruhan kinerja dari algoritma $A$-Star sudah baik dimana rute yang dipilih adalah rute yang terdekat dan musuh dapat menghindari hambatan statis yang ada selama permainan. Selain itu, musuh dapat mengejar karakter pemain secara real-time tanpa delay bahkan pada ponsel entry-level berspesifikasi rendah seperti Redmi 3S Prime yang dirilis 5 tahun yang lalu. Algoritma A-Star yang diusulkan namun memiliki keterbatasan seperti musuh cenderung untuk memilih rute pengejaran yang sama dan tidak ada kerja sama antara musuh satu dengan lain dalam mengepung pemain.

Algoritma A-Star yang telah diusulkan dapat diperbaiki lagi misalkan dengan membuat cell yang ditempati oleh musuh lain menjadi tidak dapat dilalui hanya jika mereka berjarak kurang dari 6 cell dari cell pemain. Algoritma A-Star juga perlu untuk mempertimbangkan gerakan dan hasil perhitungan A-Star musuh lain agar dapat saling bekerja sama dan mengepung pemain dari berbagai posisi. Penggunaan dynamic weighting A-Star juga dapat dipertimbangkan agar musuh dapat memprioritaskan cell strategis di peta permainan. Perbaikan-perbaikan terhadap A-Star namun dapat meningkatkan waktu komputasi secara signifikan, sehingga perlu dikombinasikan dengan iterative deepening atau bounded memory. Hal ini dilakukan agar pengejaran oleh musuh tetap bisa dilakukan secara real-time meskipun harus dengan mengorbankan sedikit akurasi karena pencarian menjadi tidak terlalu dalam. Solusi alternatif lainnya adalah melakukan prakomputasi terhadap nilai $f$ dari setiap cell sebelum permainan dirilis ke masyarakat. Hal ini dimungkinkan karena peta, hambatan, dan karakter-karakter yang ada di permainan bersifat statis.

\section{DAFTAR PUSTAKA}

[1] Silalahi, D. H.. 2019. Penanggulangan Tindak Pidana Penyalahgunaan Narkotika. 1st ed. Medan: EnamMedia.

[2] Arif, A.. 2020. Aplikasi Pengenalan Jenis Narkoba Berbasis Android Pada Badan Narkotika Nasional Kota Pagar Alam. Indones. J. Comput. Sci. 9:1 53-64.

[3] Pimpinan Pusat Gerakan Nasional Anti Narkoba. 2020. Jagalah Dirimu dan Keluargamu dari Api Narkoba. 1st ed. Jakarta: Majelis Ulama Indonesia.

[4] Tumiwa K K, dkk. 2021. Tetap Kreatif dan Inovatif di Tengah Pandemi Covid-19 (Jilid 2). 1st ed. Pekalongan: PT. Nasya Expanding Management.

[5] Wibawanto, W.. 2020. Game Edukasi RPG (Role Playing Game). 1st ed. Semarang: LPPM UNNES,

[6] Ahdiyat M A, dan Irwansyah. 2018. Analisis Keterlibatan Komunitas dalam Industri Permainan Daring di Indonesia. Interak. J. Ilmu Komun.. 7:2 105-115.

[7] Tommy L, Kirana C, dan Lindawati V. 2019. Recommender System dengan Kombinasi Apriori dan Content-Based Filtering pada Aplikasi Pemesanan Produk. J. Teknoinfo. 13:2 84 95.

[8] Sazaki Y, Satria H, Primanita A, dan Syahroyni M. 2018. Analisa Perbandingan Algoritma A* dan Dynamic Pathfinding Algorithm dengan Dynamic Pathfinding Algorithm untuk NPC pada Car Racing Game. J. Teknol. Inf. dan Ilmu Komput.. 5:1 95-103.

[9] Umar R, Yudhana A, dan Prayudi A. 2021. Analisis Perbandingan Algoritma Djikstra, A-Star, dan Floyd Warshall dalam Pencarian Rute Terdekat pada Objek Wisata Kabupaten Dompu. $J$. Teknol. Inf. dan Ilmu Komput.. 8:2 227-234.

[10] Juniawan F P, dan Sylfania D Y. 2020. Penentuan Rute Terpendek Tujuan Wisata di Kota Toboali Menggunakan Algoritme Dijkstra Berbasis Web. J. Teknol. Inf. dan Ilmu Komput.. 7: 
$1211-218$.

[11] Tommy L, dan Japriadi Y S. 2018. Implementasi Algoritma Dijkstra pada Aplikasi Pencarian Jalur Terpendek Lokasi SPBU di Pangkalpinang Berbasis Android. in Konferensi Nasional Sistem Informasi. 1018-1023.

[12] Dewi R N, Atmodjo D W P, dan Purwaningsih M. 2020. Aplikasi Penentuan Rute dan Waktu Tempuh ke Halte Transjakarta Terdekat dengan Algoritme Dijkstra Berbasis Location Base System. J. Teknol. Inf. dan Ilmu Komput.. 7:4 653-660.

[13] Musril H. A.. 2017. Penerapan Open Shortest Path First (OSPF) untuk Menentukan Jalur Terbaik dalam Jaringan. J. Elektro dan Telekomun. Terap.. 4:1 421-431.

[14] Attamimi I, Yahya W, dan Hanafi M H.. 2017. Analisis Perbandingan Algoritma FloydWarshall dan Dijkstra untuk Menentukan Jalur Terpendek Pada Jaringan Openflow. $J$. Pengemb. Teknol. Inf. dan Ilmu Komput.. 1:12 1842-1849.

[15] Wayahdi M R, Ginting S H N, dan Syahputra D. 2021. Greedy, A-Star, and Dijkstra's Algorithms in Finding Shortest Path. Int. J. Adv. Data Inf. Syst. 2:1 45-52.

[16] Zainulhayat L, dan Purwanto T H. 2017. Perbandingan Rute Optimum Hasil Perhitungan Algoritma Dijkstra dan A-Star untuk Sirkulasi Paket Jasa Ekspedisi JNE di D.I. Yogyakarta. J. Bumi Indones. 6:3 1-10.

[17] Maaruf K. C.. 2016. Kecerdasan Buatan Menggunakan Algoritma A Star (A*) dalam Permainan Ular Tangga (Snake 3D). in Seminar Nasional Teknologi Informasi dan Multimedia. 19-24.

[18] Widodo W, dan Ahmad I. 2017. Penerapan Algoritma A Star (A*) pada Game Petualangan Labirin Berbasis Android. Khazanah Inform. J. Ilmu Komput. dan Inform.. 3:2 57-63.

[19] Umami N A, Agustina I, dan Fauziah. 2018. Rancang Bangun Game Android Adventure Finding Diamond dengan Unity 3D Menggunakan Metode Dynamic Weighting A*. JOINTECS (Journal Inf. Technol. Comput. Sci.. 3:1 45-50.

[20] Hermanto D, dan Dermawan S.. 2018. Penerapan Algoritma A-Star Sebagai Pencari Rute Terpendek pada Robot Hexapod. J. Nas. Tek. Elektro. 7:2 122-129.

[21] Putra A B W, Rachman A A, Santoso A, dan Mulyanto. 2020. Perbandingan Hasil Rute Terdekat Antar Rumah Sakit di Samarinda Menggunakan Algoritma A*(star) dan FloydWarshall. J. Sisfokom (Sistem Inf. dan Komputer). 9:1 59-68.

[22] Colls M G, dan Martínez de Osés F X.. 2016. A Ship Routing System Applied at Short Sea Distances. J. Marit. Res.. 13:2 3-6. 